\title{
Pengaruh Penggunaan Zat Aditif Tipe C pada Kekuatan Tekan Beton
}

\author{
Zamroni $^{{ }^{*}}$, Eka Susanti ${ }^{1}$, Dita Kamarul Fitriyah ${ }^{1}$ \\ ${ }^{1}$ Program Studi Teknik Sipil, Fakultas Teknik Sipil dan Perencanaan, Institut Teknologi Adhi Tama Surabaya \\ Email: "zamroni.zamroni2000@gmail.com
}

\begin{abstract}
In the construction industry the development and use of mixed cement is increasing. This aims to minimize the use of cement. The use of fly ash as a substitute material to reduce the amount of cement has advantages, including saving costs and reducing negative impacts on the environment. However, based on recent research, it was found that the use of fly ash above $30 \%$ will reduce the compressive strength of concrete. The use of additives serves to ease the work or speed up the bonding to concrete with the intention of shortening the construction time in the field. The percentage of use of fly ash is limited to a percentage of 30\% - 40\% of the weight of cement. Under normal conditions, the compressive strength of concrete will increase as the concrete ages. In general, at the age of 7 days, the compressive strength of concrete will reach $65 \%$ and at the age of 14 days it will reach $88 \%$ - 90\% of the compressive strength of concrete at 28 days. In this study, it was found that the compressive strength for normal concrete and concrete with fly ash has decreased strength against normal concrete for ages 14, 28, 56 days. The highest percentage reduction in strength occurred in the use of fly ash by $40 \%$ on the 56th day, which was $-7.66 \%$ for normal concrete. But it still fulfills the compressive strength of the plan in 28 days of concrete, which is $25.99 \mathrm{MPa}$.
\end{abstract}

Keywords: Reinforced Concrete, Fly Ash, Compressive Strength, Additives

\begin{abstract}
Abstrak
Pengembangan dan penggunaan semen campuran semakin meningkat dalam industry konstruksi. Hal ini bertujuan untuk meminimalisir penggunaan semen. Penggunaan Fly ash yang banyak digunakan pada material pengganti untuk mengurangi jumlah semen, memiliki kelebihan, diantaranya menghemat biaya dan mengurangi efek negatif pada lingkungan hidup. Akan tetapi, berdasarkan penelitian mutakhir, didapatkan bahwa penggunaan fly ash diatas $30 \%$ akan menurunkan kuat tekan beton. Penggunaan zat aditif berfungsi untuk kemudahan pengerjaan ataupun mempercepat pengikatan pada beton dengan maksud mempersingkat waktu pelaksanaan konstruksi di lapangan. Prosentase penggunaan fly ash terbatasa pada prosentase $30 \%-40 \%$ dari berat semen. Pada kondisi normal, kuat tekan beton akan meningkat sesuai bertambahnya umur beton. Pada umumnya pada umur 7 hari, kuat tekan beton akan mencapai $65 \%$ dan pada umur 14 hari akan mencapai 88\% - 90\% dari kuat tekan beton umur 28 hari. Dalam penelitian ini didapatkan bahwa terjadi penurunan kekuatan terhadap beton normal untuk umur 14, 28, 56 hari pada kekuatan tekan untuk beton normal dan beton dengan fly ash. Persentase penurunan kuat beton tertinggi terjadi pada pemakaian fly ash sebesar $40 \%$ pada hari ke-56, yaitu sebesar $-7,66 \%$ terhadap beton normal. Tetapi masih memenuhi kuat tekan rencana diumur beton 28 hari yaitu 25,99 Mpa.
\end{abstract}

Kata Kunci: Beton Bertulang, Fly Ash, Kuat Tekan, Zat Aditif

\section{Pendahuluan}

Dalam industri konstruksi pengembangan dan penggunaan semen campuran semakin meningkat. Hal ini bertujuan untuk meminimalisir penggunaan semen. Penggunaan fly ash sebagai bahan pengganti untuk meminimalisir penggunaan jumlah semen, memiliki kelebihan, diantaranya menghemat biaya dan mengurangi dampak negatif pada lingkungan. Penggunaan fly ash juga mengurangi rata-rata ukuran pori pada beton sehingga diperoleh permeabilitas beton yang lebih kecil. Kandungan silica dan alumina fly ash mencapai prosentase $80 \%$, hal ini membuat fly ash memiliki kemiripan sifat - sifat seperti semen[1]. 
Hasil penelitian Alfian Hendri Umboh, 2014[2], menunjukkan bahwa penggunaan campuran fly ash hingga 30\%, masih dapat mencapai kuat tekan beton rencana pada usia beton 28 hari. Dan penggunaan fly ash diatas $30 \%$, menurunkan kuat tekan beton.

Dalam kadar tertentu, kelembaban yang cukup dan suhu kamar, kandungan senyawa silika dan alumina pada fly ash, akan mengikat senyawa sisa hasil hidrasi semen yang tidak mempunyai kemampuan mengikat, menjadi senyawa baru yang mempunyai sifat cementitious (mengikat). Sehingga kuat tekan beton akan makin meningkat setelah usia 28 hari[3]. Hal ini sesuai dengan hasil penelitian Sebayang 2015 [4], semakin banyak penggunaan fly ash, maka kuat tekan beton 28 hari akan semakin banyak mengalami peningkatan di umur 56 hari.

Dalam dunia konstruksi terdapat zat aditif yang berfungsi mempercepat pengikatan sebagai upaya menghasilkan beton dengan kemampuan cepat mengeras dengan tujuan agar kecepatan pelaksanaan konstruksi dapat lebih ditingkatkan. Untuk itu diperlukan penggunaan bahan tambah yang berfungsi untuk mempercepat pengikatan dan pengembangan kekuatan awal beton. Bahan ini digunakan untuk mengurangi lamanya waktu pengeringan (hidrasi), dan mempercepat pencapaian kekuatan beton. Zat aditif tersebut adalah zat aditif tipe C (Accelerator).

Dari penjelasan diatas, penelitian ini dimaksudkan untuk perbaikan pada hasil penelitian Umboh 2014 [3]. Tujuannya memperbesar prosentase penggunaan fly ash dengan tetap mempertahankan tercapainya mutu beton rencana, caranya dengan menambahkan zat aditif tipe $\mathrm{C}$ (Accelerator) dari berat total bahan pengikat. Prosentase penggunaan fly ash terbatas pada prosentase $30 \%$ dan $40 \%$ dari berat semen.

\section{Metode}

Adapun metodologi penelitian yang dilakukan untuk mencapai tujuan yang dimaksud yaitu sebagai berikut :

a) Studi Literatur

Studi pustaka dilakukan dengan mendalami materi yang relevan dengan penelitian ini. Kepustakaan ini meliputi berbagai buku teks, peraturan dan standar nasional yang dicantumkan pada daftar pustaka.

b) Metode Penelitian

Pada penelitian ini, metode pembuatan yang akan dilakukan yaitu dengan mengurangi jumlah semen yang dipakai dalam komposisi beton, ditentukan dengan menambahkan persentase fly ash dan pengujian menggunakan sejumlah benda uji beton silinder ( $\varnothing 15 \mathrm{~cm}$, tinggi $30 \mathrm{~cm}$ ). Benda uji tersebut dibuat di laboratorium RAJA BETON. Beton dengan mutu fc' 25 menyatakan kekuatan tekan minimum adalah $25 \mathrm{MPa}$ pada umur beton 28 hari, dengan menggunakan silinder beton diameter $15 \mathrm{~cm}$, tinggi 30 $\mathrm{cm}$. Mengacu pada standar SNI 03-2847-2002 yang merujuk pada ACI 136 [5] Jumlah total benda uji tersebut sebanyak 135 buah (terdapat 4 varian dan tiap varian terdiri dari 15 buah benda uji), dengan perpaduan komposisi menggunakan fly ash $0 \%, 30 \%$ dan $40 \%$. Kemudian diuji kuat tekan pada usia 14,28 dan 56 hari untuk mencari varian yang memiliki kuat tekan paling optimum.

c) Parameter Penelitian

Parameter yang digunakan dalam penelitian ini meliputi:

a. Penelitian dan pengujian bahan secara fisik

b. Pengujian kuat tekan beton pada umur 14 hari, 28 hari dan 56 hari

c. Pengaruh penambahan accelerator terhadap beton normal dan beton dengan $30 \%$ fly ash

d. Berapa standar deviasi yang tercapai pada pencampuran beton normal dengan beton penambahan $30 \%$ fly ash

d) Persiapan Peralatan dan Bahan

Menyiapkan bahan yaitu pasir agregat halus \& kasar, air, semen portland tipe I, serta fly ash. Kemudian, berbagai peralatan yang digunakan dalam pengujian bahan dan benda uji.

e) Metodologi Pengujian 
Dalam melakukan metodologi pengujian, acuan yang dipakai adalah SNI 2493-2011 [6] adapun beberapa pengujian yaitu sebagai berikut :

a. Pengujian agregat halus

- Analisa saringan agregat halus, berdasarkan (ASTM C 136-95A)

- Analisa Berat Jenis agregat halus, berdasarkan (ASTM C 128 - 93)

- Analisis kadar Air resapan agregat halus, berdasarkan (ASTM C 128 - 93)

- Analisa kebersihan agregat halus terhadap bahan organik, berdasarkan (ASTM C 40 - 92)

- Analisa Kebersihan Pasir Terhadap Lumpur dengan cara (Pencucian), berdasarkan (ASTM C 117 - 95)

- Analisa Berat Volume Pasir agregat halus, berdasarkan (ASTM C 29 / C 29 M - 91)

b. Pengujian agregat kasar

- Analisa saringan agregat Kasar, berdasarkan ASTM C 136 - 95A [7]

- Analisa Berat Jenis agregat Kasar, berdasarkan (ASTM C 127 - 88 Reapp 93)

- Analisis kadar Air resapan agregat Kasar, berdasarkan (ASTM C 127 - 88 Reapp 93)

- Analisa Kebersihan Kerikil Terhadap Lumpur dengan cara (Pencucian), berdasarkan (ASTM C 117 - 95)

- Analisa Berat Volume Kerikil agregat halus, berdasarkan (ASTM C 29 / C 29 M - 91)

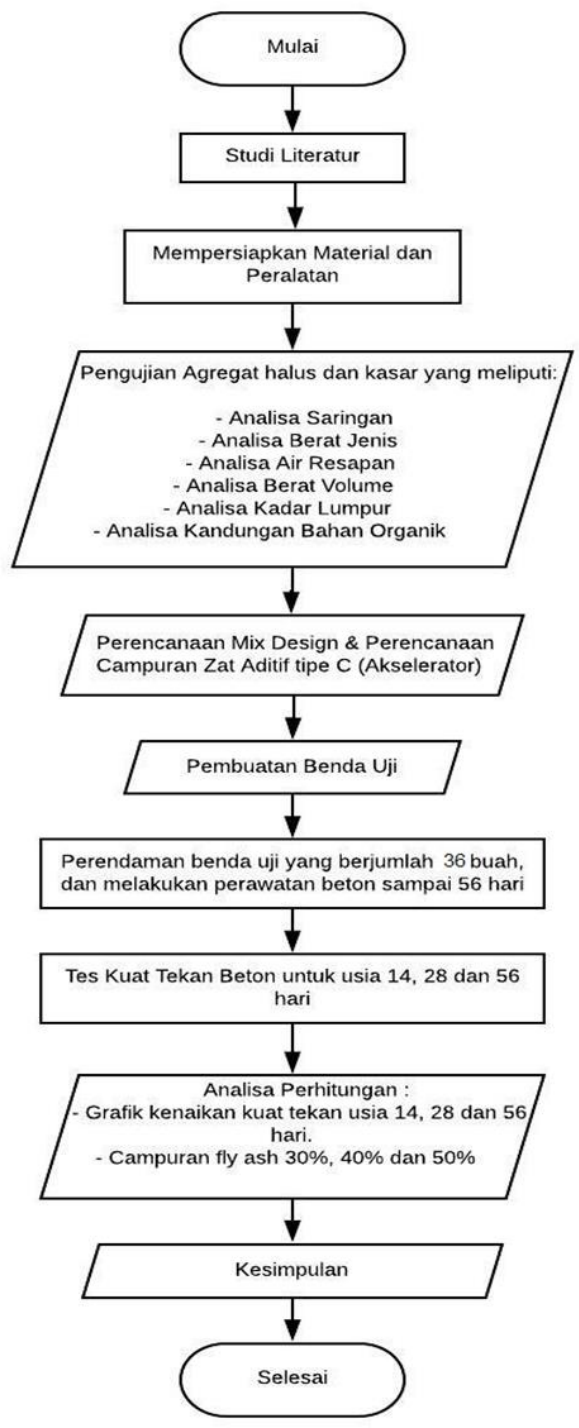

Gambar 1. Diagram Alir Pelaksanaan Penelitian 
f) Prosedur Pembuatan Benda Uji (ASTM C 192-90A)

Sesudah mendapat hasil perhitungan dari perhitungan mix design, metode selanjutnya yaitu membuat campuran beton. Setelah semua agregat tercampur rata, lau mengambil sebagian campuran beton atau pasta beton itu dengan sendok spesi untuk dilakukan tes berat volume beton dan uji slump.

Membuat cetakan beton dengan cetakan silinder $\varnothing 15 \mathrm{~cm}$ dan tinggi $30 \mathrm{~cm}$, sambil dipadatkan dengan menggunakan alat perojok setiap $1 / 3$ bagiannya sampai penuh. Lalu, didiamkan selama 24 jam. Sesudah 24 jam benda uji dikeluarkan dari dalam cetakan, lalu merendam benda uji di bak perendam yang berisi air selama 28 hari.

g) Prosedur Pelaksanaan Beton

Pada penelitian ini perencanaan mix design menggunakan metode DOE sesuai aturan SNI 032847-2002. Berikut isian mix design menggunakan metode DOE dengan komposisi campuran beton mutu $F^{\prime} c^{\prime} 25$ Mpa.

h) Slump Test

Slump test digunakan untuk menentukan konsistensi/kekuatan dari campuran beton segar untuk menentukan tingkat workability nya. Kekakuan dalam suatu sampuran beton menunjukkan berapa banyak air yang digunakan. Untuk itu uji slump menunjukkan apakah campuran beton kekurangan, kelebihan, atau cukup air. Menurut SNI 1972:2008 Cara Uji Slump Beton.

i) Perawatan Benda Uji (Curing)

Setelah pelaksanaan pembuatan benda uji, maka dilakukan perawatan benda uji Beton silinder ukuran $15 \mathrm{~cm}$ dan tinggi $30 \mathrm{~cm}$ dengan ketentuan ASTM C $31-09$. Curing/perawatan beton bertujuan untuk menjaga dan menjamin mutu pelaksanaan pembetonan.

\section{j) Pengujian Kuat Tekan Beton}

Uji kuat tekan dilaksanakan di laboratorium PT. Restu Anak Jaya Abadi Beton Indonesia dan pengujian ini kita lakukan untuk mengetahui kuat tekan beton yang telah mengeras dengan benda uji berbentuk silinder. Pembebanan dilakukan sampai silinder beton hancur dan dicatat besarnya beban maksimum P (MPa). Dan selanjutnya digunakan untuk menentukan tekan beton $\left(f^{\prime} c\right)$.

\section{Hasil dan Pembahasan}

Penelitian ini bertujuan meningkatkan kuat tekan beton pada penelitian sebelumnya, dimana campuran beton tersebut mengunakan fly ash $30 \%$ sebagai pengganti semen. Sesuai penelitian terdahulu, maka penelitian ini juga menggunakan kuat tekan beton rencana 25Mpa dan fas 0,47. Peningkatan kuat tekan beton diusahakan dengan menambahkan dari berat total bahan pengikat.

Adapun hasil pengujian agregat halus telah memenuhi persyaratan SNI yang dirujuk, dapat dilihat pada Tabel 1.

Tabel 1. Hasil Pengujian Agregat Halus

\begin{tabular}{|c|c|c|c|c|c|}
\hline No & Percobaan & Pasir Lumajang & Standart & Keterangan & Peraturan \\
\hline a & Kelembaban & $1,30 \%$ & $1-5 \%$ & Memenuhi & ASTM C 556-89 \\
\hline b & Berat Jenis & $2,67 \mathrm{gr} / \mathrm{cm}^{3}$ & $1,60-3,30 \mathrm{gr} / \mathrm{cm}^{3}$ & Memenuhi & ASTM C127-93 \\
\hline c & Air Resapan & $2,57 \%$ & Maks $5 \%$ & Memenuhi & ASTM C 127 - 93 \\
\hline d & $\begin{array}{c}\text { Berat Volume } \\
(\text { Lepas })\end{array}$ & $1,56 \mathrm{~kg} / \mathrm{dm}^{3}$ & $0,4-1,9 \mathrm{~kg} / \mathrm{dm}^{3}$ & Memenuhi & $\begin{array}{c}\text { ASTM C 29/ } \\
\text { C 29 M - } 91\end{array}$ \\
\hline
\end{tabular}




\begin{tabular}{|c|c|c|c|c|c|}
\hline & $\begin{array}{c}\text { Berat Volume } \\
\text { (Rojok) }\end{array}$ & $1,60 \mathrm{~kg} / \mathrm{dm}^{3}$ & $0,4-1,9 \mathrm{~kg} / \mathrm{dm}^{3}$ & Memenuhi & $\begin{array}{c}\text { ASTM C 29/ } \\
\text { C 29 M }-91\end{array}$ \\
\hline $\mathbf{e}$ & Kadar Lumpur & $2,4 \%$ & Maks 5\% & Memenuhi & ASTM C 117 -95 \\
\hline $\mathbf{f}$ & Kadar Bahan Organik & No.3 & No.6 & Memenuhi & ASTM C 40-92 \\
\hline $\mathbf{g}$ & Analisa Saringan & $\begin{array}{c}\text { Zona } 2 \\
(\mathrm{Fm}=2,41)\end{array}$ & $2,0<\mathrm{Fm}<3,1$ & Memenuhi & $\begin{array}{c}\text { ASTM C 136 - 95A } \\
\text { (ASTM C 33) }\end{array}$ \\
\hline
\end{tabular}

Sumber : Hasil Analisis, 2020.

Begitu juga hasil pengujian pada agregat kasar juga telah memenuhi persyaratan SNI yang dirujuk, dapat dilihat pada Tabel 2.

Tabel 2. Hasil Pengujian Agregat Kasar 10 - 20 Pandaan

\begin{tabular}{|c|c|c|c|c|c|}
\hline No & Percobaan & Pasir Lumajang & Standart & Keterangan & Peraturan \\
\hline $\mathbf{a}$ & Kelembaban & $1,62 \%$ & $1-5 \%$ & Memenuhi & ASTM C $556-89$ \\
\hline $\mathbf{b}$ & Berat Jenis & $2,78 \mathrm{gr} / \mathrm{cm}^{3}$ & $1,60-3,30 \mathrm{gr} / \mathrm{cm}^{3}$ & Memenuhi & ASTM C128-93 \\
\hline $\mathbf{c}$ & Air Resapan & $1,23 \%$ & Maks $4 \%$ & Memenuhi & ASTM C $128-93$ \\
\hline d & $\begin{array}{c}\text { Berat Volume } \\
\text { (Lepas) }\end{array}$ & $1,35 \mathrm{~kg} / \mathrm{dm}^{3}$ & $0,4-1,9 \mathrm{~kg} / \mathrm{dm}^{3}$ & Memenuhi & $\begin{array}{c}\text { ASTM C 29/ } \\
\text { C } 29 \text { M - } 91\end{array}$ \\
\hline & $\begin{array}{l}\text { Berat Volume } \\
\text { (Rojok) }\end{array}$ & $1,5 \mathrm{~kg} / \mathrm{dm} 3$ & $0,4-1,9 \mathrm{~kg} / \mathrm{dm}^{3}$ & Memenuhi & $\begin{array}{c}\text { ASTM C 29/ } \\
\text { C } 29 \text { M - } 91\end{array}$ \\
\hline e & Kadar Lumpur & $2,1 \%$ & Maks 5\% & Memenuhi & ASTM C $117-95$ \\
\hline f & Analisa Saringan & $\mathrm{Fm}=7,35$ & $6,5<\mathrm{Fm}<8,0$ & Memenuhi & ASTM C 33 \\
\hline
\end{tabular}

Sumber : Hasil Analisis, 2020.

Setelah pengujian agregat terpenuhi, maka dilakukan perhtungan mix design untuk mendapatkan proporsi bahan yang tepat, guna mencapai kuat tekan yang diharapkan. Maka didapatkan tiap m3 yaitu Semen $436 \mathrm{Kg}$, Agregat halus $628 \mathrm{Kg}$, agregat kasar $1166 \mathrm{Kg}$, dan air 205 Liter. Setelah dilakukan pembuatan benda uji hingga proses curing, Maka dilakukan uji tekan yang ditinjau pada umur beton 7, 14 dan 28 hari. Dapat dilihat pada Tabel 3.

Tabel 3. Hasil Uji Kuat Tekan Beton pada Umur 7, 14 dan 28 Hari

\begin{tabular}{|c|c|c|c|c|c|c|c|c|c|c|c|c|}
\hline \multirow[t]{4}{*}{ No. } & \multicolumn{3}{|c|}{$\begin{array}{c}\text { Fc } 25 \text { Mpa } \\
\text { Beton Normal }\end{array}$} & \multicolumn{3}{|c|}{$\begin{array}{c}\text { Fc } 25 \text { Mpa } \\
\text { Beton Normal + } \\
\text { accelerator }\end{array}$} & \multicolumn{3}{|c|}{$\begin{array}{c}\text { Fc } 25 \text { Mpa } \\
\text { Fly Ash } 30 \% \text { + accelerator }\end{array}$} & \multicolumn{3}{|c|}{$\begin{array}{c}\text { Fc } 25 \text { Mpa } \\
\text { Fly Ash } 40 \%+ \\
\text { accelerator }\end{array}$} \\
\hline & \multicolumn{12}{|c|}{ Kuat Tekan pada berbagai umur 14 Hari, 28 Hari, dan 56 Hari (MPa) } \\
\hline & 14 & 28 & 56 & 14 & 28 Hari & 56 & 14 & 28 & 56 & 14 & 28 & 56 \\
\hline & Hari & Hari & Hari & Hari & & Hari & Hari & Hari & Hari & Hari & Hari & Hari \\
\hline 1 & 24,46 & 27,75 & 28,60 & 25,63 & 27,86 & 28,88 & 23,78 & 26,33 & 26,73 & 23,10 & 26,05 & 26,16 \\
\hline 2 & 24,63 & 27,46 & 27,75 & 25,20 & 27,46 & 28,77 & 23,90 & 26,61 & 26,90 & 23,50 & 26,16 & 25,76 \\
\hline 3 & 24,86 & 27,18 & 27,86 & 25,59 & 27,18 & 28,31 & 23,67 & 26,50 & 27,18 & 22,76 & 25,76 & 25,82 \\
\hline
\end{tabular}

Sumber : Hasil Analisis, 2020.

Dari Tabel 3 Hasil uji kuat tekan beton pada umur 14, 28, dan 56 hari diatas maka dapat diperoleh Nilai kuat tekan rata - rata beton seperti berikut (Tabel 4) :

Tabel 4. Hasil Uji Kuat Tekan Beton rata - rata pada umur 14,28 dan 56 Hari

\begin{tabular}{|c|l|c|c|c|}
\hline \multirow{2}{*}{ No } & \multicolumn{1}{|c|}{ Uji } & \multicolumn{3}{|c|}{ Kuat Tekan Rata - rata } \\
\cline { 2 - 6 } & \multicolumn{1}{|c|}{ Umur (Hari) } & 14 & 28 & 56 \\
\hline $\mathbf{1}$ & Fc 25 Mpa Beton Normal & 24,65 & 27,46 & 28,07 \\
\hline $\mathbf{2}$ & Fc 25 Mpa Beton Normal + accelerator & 25,27 & 27,50 & 28,65 \\
\hline $\mathbf{3}$ & Fc 25 Mpa Fly Ash 30\% + accelerator & 23,78 & 26,48 & 26,93 \\
\hline $\mathbf{4}$ & Fc 25 Mpa Fly Ash 40\% + accelerator & 23,12 & 25,99 & 25,92 \\
\hline
\end{tabular}


Sumber : Hasil Analisis, 2020.

Dari Tabel 4. Hasil uji kuat tekan rata - rata beton pada umur 14, 28, dan 56 hari diatas maka dapat dibuat Grafik seperti berikut (Gambar 2.) :
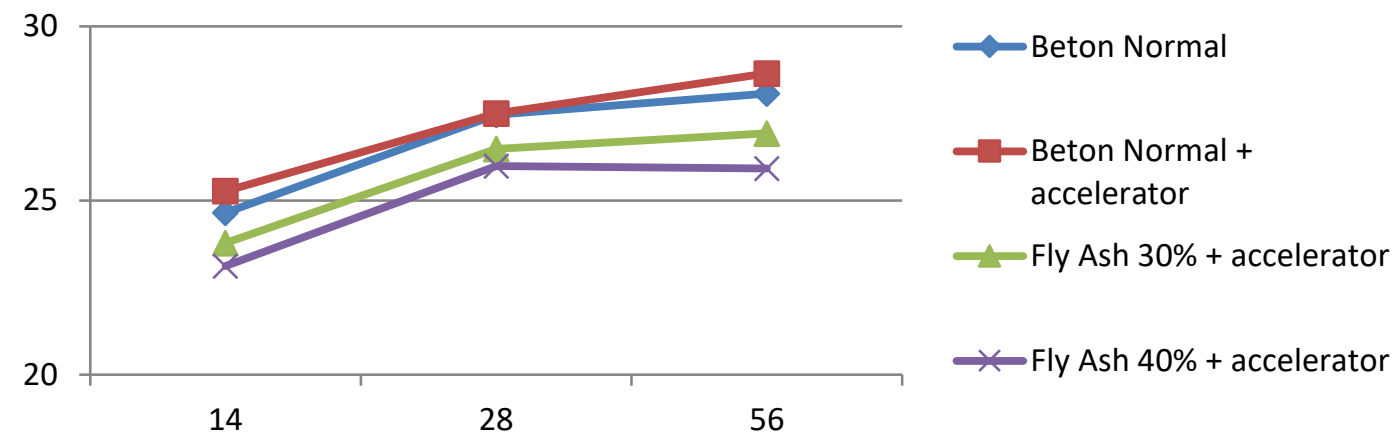

\section{Gambar 2. Perbandingan Kuat Tekan Beton Rata Rata pada Umur 14, 28 dan 56 Hari.}

Berdasarkan Gambar 2 dapat diambil kesimpulan bahwa kekuatan tekan beton akan meningkat sesuai dengan bertambahnya umur beton. Umumnya pada umur 7 hari kuat tekan mencapai $65 \%$ dan pada umur 14 hari mencapai 88\% - 90\% dari kuat tekan beton umur 28 hari. (Peraturan Beton bertulang Indonesia, 1971).

Dilakukan perbandingan kuat tekan beton normal dengan beton dengan fly ash $40 \%+$ accelerator, dapat dilihat pada Tabel 5 .

Tabel 5. Hasil Prosentase Kekuatan Beton

\begin{tabular}{|l|c|c|c|}
\hline \multicolumn{1}{|c|}{ ARIASI BENDA UJI } & $\begin{array}{c}\text { UMUR } \\
\text { BENDA UJI }\end{array}$ & $\begin{array}{c}\text { KUAT TEKAN } \\
\text { BETON }\end{array}$ & PENURUNAN (\%) \\
\hline Beton Normal & 14 & 24,65 & 0,00 \\
\hline Fly Ash 40\% + Accelerator & 14 & 23,12 & $-6,21$ \\
\hline Beton Normal & 28 & 27,46 & 0,00 \\
\hline Fly Ash 40\% + Accelerator & 28 & 25,99 & $-5,35$ \\
\hline Beton Normal & 56 & 28,07 & 0,00 \\
\hline Fly Ash 40\% + Accelerator & 56 & 25,92 & $-7,66$ \\
\hline
\end{tabular}

Sumber : Hasil Perhitungan, 2020.

Dari Tabel 5 dapat dilihat bahwa nilai kekuatan tekan untuk beton normal dengan beton yang ditambahkan fly ash mengalami penurunan kekuatan terhadap beton normal untuk umur 14, 28, 56 hari. Persentase penurunan kekuatan tertinggi terjadi pada penambahan fly ash sebesar $40 \%$ pada hari ke-56, yaitu sebesar $-7,66 \%$ terhadap beton normal. Tetapi masih memenuhi kuat tekan rencana diumur beton 28 hari yaitu 25,99 Mpa.

Tabel 6. Pengaruh Accelerator terhadap Kekuatan Tekan Beton Normal dan campuran beton

\begin{tabular}{|c|l|c|c|c|}
\hline \multirow{2}{*}{ No } & \multicolumn{1}{|c|}{ Uji } & \multicolumn{3}{c|}{ Kuat Tekan Rata - rata } \\
(Mpa)
\end{tabular}


Sumber : Hasil Perhitungan, 2020.

Jika melihat Tabel 6 dapat diambil kesimpulan bahwa accelerator dapat meningkatkan kuat tekan beton terutama memasuki usia beton 14, 28 dan 56 Hari. Kemudian, pengaruh accelerator lebih signifikan pada beton normal, daripada beton campuran $30 \%$ fly ash.

Baik tidaknya kualitas pengerjaan beton dapat dilihat dari besar kecilnya nilai deviasi standar, makin kecil nilai deviasi standar, maka makin baik mutu pengerjaannya. Dari Tabel 7, deviasi standar rata - rata yang dihasilkan sebesar 0,26. Apabila dibandingkan dengan standart yang diberikan oleh ACI (Yogi 2012), tabel 4.10, maka nilai Standart deviasi 0,26<1,5 dan termasuk dalam kategori pengerjaan beton di laboratorium dengan kategori sempurna.

Tabel 7. Deviasi Standar Rata - Rata

\begin{tabular}{|l|c|c|c|c|}
\hline \multirow{2}{*}{ Keterangan } & \multicolumn{3}{|c|}{ usia beton } & \multirow{2}{*}{ Rata2 } \\
\cline { 2 - 4 } & 14 & 28 & 56 & \\
\hline Standart Deviasi beton normal & 0,02 & 0,29 & 0,46 & 0,32 \\
\hline Standart Deviasi beton normal + acc & 0,24 & 0,34 & 0,3 & 0,29 \\
\hline $\begin{array}{l}\text { Standart Deviasi beton dg 30\% FA + } \\
\text { acc }\end{array}$ & 0,12 & 0,14 & 0,23 & 0,16 \\
\hline $\begin{array}{l}\text { Standart Deviasi beton dg 40\%FA + } \\
\text { acc }\end{array}$ & 0,37 & 0,21 & 0,22 & 0,26 \\
\hline \multicolumn{4}{|l}{ Standart Deviasi rata2 } \\
\hline
\end{tabular}

Sumber : Hasil Perhitungan, 2020.

\section{Kesimpulan}

Dari penelitian yang sudah diakukan dapat disimpulkan bahwa Accelerator dapat meningkatkan nilai kekuatan tekan beton normal dan Penambahan fly ash $30 \%$ pada campuran beton normal dapat menurunkan nilai kuat tekan beton mencapai $3,53 \%$, tetapi dengan adanya penambahan accelerator, mampu meningkatkan kuat tekan beton hingga $2 \%$.

\section{Referensi}

[1] A. Maryoto and G. Pamudji, "Program Studi Teknik Sipil Unsoed," Din. Rekayasa, vol. 4, no. 1, pp. 41-49, 2008, [Online]. Available: http://dinarek.unsoed.ac.id/jurnal/index.php/dinarek/article/viewFile/132/132.

[2] A. H. Umboh, "Pengaruh pemanfaatan abu terbang ( fly ash ) dari pltu ii sulawesi utara sebagai substitusi parsial semen terhadap kuat tekan beton," Surya Sebayang, vol. 2, no. 7, pp. 352-358, 2014.

[3] A. P. Marthinus and R. S. W. Marthin D. J. Sumajouw, "Pengaruh penambahan abu terbang ( fly ash) terhadap kuat tarik belah beton," J. Sipil Statik, vol. 3, no. 11, pp. 729-736, 2015.

[4] S. Sebayang, "Pengaruh Kadar Abu Terbang Sebagai Pengganti Sejumlah Semen Pada Beton Alir Mutu Tinggi," pp. 1-27, 2015.

[5] W. J. Halstead, "Use of Fly Ash in Concrete.," Natl. Coop. Highw. Res. Program, Synth. Highw. Pract., vol. 96, no. Reapproved, pp. 1-34, 1986.

[6] SNI 2493-2011, "Tata Cara Pembuatan dan Perawatan Benda Uji Beton di Laboratorium," Badan Standar Nas. Indones., p. 23, 2011, [Online]. Available: www.bsn.go.id.

[7] ASTM, “ASTM C 136 - 95A," Hrvat. Vode, vol. 13, no. 50, pp. 85-86, 2005. 